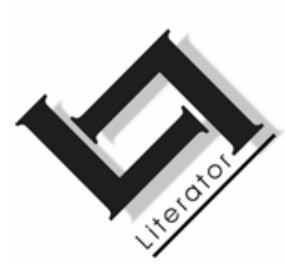

\title{
Identity, difference and healing: Reading Beloved within the context of John Caputo's theory of hermeneutics
}

\author{
Belinda du Plooy \& Pamela Ryan \\ Department of English \\ University of South Africa 1 \\ PRETORIA \\ E-mail: belinda.duplooy@nmmu.ac.za \\ ryanpd@unisa.ac.za
}

\begin{abstract}
Identity, difference and healing: Reading Beloved within the context of John Caputo's theory of hermeneutics
\end{abstract}

John Caputo's interest in the human struggle towards healing/wholing is obvious in his contribution on the work of Foucault: "On not knowing who we are: Madness, hermeneutics, and the night of truth in Foucault" (Caputo, 1993:233-262). While basing his reading of madness as a form of human suffering on the work of Foucault, Caputo moves beyond Foucaultian theory - "in a direction that, while it was not taken by Foucault, is perhaps suggested by him" (Caputo, 1993:234) - by envisioning a hermeneutics of response and redress and a therapeutics of "healing gestures" (Caputo, 1993:234). In this article we investigate the applicability of Caputo's theory of progressive Foucaultian hermeneutics to Toni Morrison's "Beloved", a work of historical fiction. (Morrison is an African-American author and Nobel laureate.) We do this investigation by reading the novel's three major characters (Sethe, Beloved and Denver) as symbolic representations of Caputo's three kinds of hermeneutics, of which the

1 I gratefully acknowledge the assistance of the University of South Africa's Department of English in providing me with the infrastructure necessary to do this research. This article is based on my M.A. completed under supervision of Prof. Pamela Ryan of the above-mentioned department. I would like to express my gratitude to Prof. Ryan for her assistance and guidance during my studies and in the writing of this article. 
third, represented by the character Denver, is constitutive of a therapeutics of healing.

\section{Opsomming}

\section{Identiteit, verskil en heling/heelwording: Beloved gelees binne die konteks van John Caputo se teorie oor hermeneutiek}

John Caputo se belangstelling in heling en/of heelwording is duidelik in sy artikel oor die werk van Foucault: "On not knowing who we are: Madness, hermeneutics, and the night of truth in Foucault" (Caputo, 1993:233-262). Caputo onderskryf Foucault se siening as hy waansin/geestelike versteurdheid/nie-redelikheid interpreteer as 'n vorm van menslike lyding. Hy voer die argument egter verder as Foucault - en wel in 'n rigting wat Foucault dalk nie self ingeslaan het nie, maar wat moontlik deur hom gesuggereer is (Caputo, 1993:234). Caputo stel naamlik 'n hermeneutiek van respons en herstel voor, asook 'n terapie wat hy baseer op "helende gebare" (Caputo, 1993:234). In hierdie artikel ondersoek ons die toepaslikheid van Caputo se teorie van 'n voortgaande Foucaultiaanse hermeneutiek op Toni Morrison se historiese roman "Beloved". (Morrison is " $n$ AfroAmerikaanse skrywer en Nobelpryswenner vir letterkunde.) Ons ondersoek hierdie moontlikheid deur die roman se drie hoofkarakters - Sethe, Beloved en Denver - te lees as simboliese uitbeeldings van Caputo se drie tipes hermeneutiek. Ons konsentreer veral op Denver as verteenwoordigend van Caputo se derde tipe hermeneutiek en as verteenwoordigend van sy voorgestelde helingsterapie.

\section{Contextualising Beloved}

Beloved contributes, as do all Toni Morrison's other texts, to the project of postcolonial excavation and reconstruction of marginalised identities and histories. Set in America during the height of the slave system and post-abolition reconstruction, Beloved actively interrogates and subverts the oppressive socio-economic and sociocultural traditions of slavery and patriarchy and their painful effects on African Americans. As a "neoslave narrative" (Kella, 2000:115) Beloved's reconstitution and representation of the painful history of America speaks not of hegemonic master narratives but of smaller, personal stories and individual histories which microscopically reflect the suffering, survival and healing of African-American individuals and communities.

Morrison has said that she writes "about love and ... how to survive whole in a world where we are all of us, in some measure, victims of something" (see Joyner, 1980:243-247). Her novels build on themes that speak of racially, culturally and gender-specific experiences, yet they simultaneously transcend narrative specificity to touch on the 
greater human themes of community, history, memory, "self-love and self-worth" (Bjork, 1992:29), love of others and surviving in a divided world. While the pain and suffering of women form the specific context within which Morrison locates her narrative, Beloved is not merely a representation of female pain and suffering, it is also a "healing ritual" (Christian, 1993), a "fixing ceremony" (Morrison, 1988:86) and a "creative engagement" with healing practices (Martin, 1996:104). Thus this novel functions as a vehicle by means of which Morrison engages with and, in final instance, transcends the pain and suffering of slavery and its many abuses by means of the character of Denver. We read Morrison's engagement with human experiences of pain and suffering as an attempt at existential interpretation and the fixing of some form of existential meaning to otherwise incomprehensible human acts of violence and violation. It is in this context that we link Beloved to John Caputo's hermeneutic engagement with Foucault's work.

\section{Caputian hermeneutics applied to Beloved}

Caputo utilises the concept hermeneutics as denoting "the inescapability of interpretation, the necessity we are under to construe the world, to engender meaning, to produce a rendering of things, of the world and one another" (Caputo, 2003). He (Caputo, 1993:233) sees Foucaultian hermeneutics as "a hermeneutics that confesses from the start that we do not know who we are, and it is a hermeneutics of who we are not". Caputo interprets Foucaultian hermeneutics as a development or progression from one kind of hermeneutics, which he calls a "tragic hermeneutics", towards another kind, a "hermeneutics of refusal" (Caputo, 1993:233). Tragic hermeneutics is constitutive of, and equivalent to a hermeneutics of identity, that is interpreting "who we are", or "who we are not" (Caputo, 1993:233). A hermeneutics of refusal is also a hermeneutics of difference: interpreting how we refuse and resist definition and definitive identification. Finally, Caputo moves beyond Foucaultian theory by envisioning a third kind of hermeneutics, that is one of response and redress, which he also reads as a therapeutics of "healing gestures" (Caputo, 1993:234).

The three kinds of hermeneutics that Caputo identifies in Foucaultian theory dovetail in Morrison's representation of the three major characters in Beloved, namely Sethe, Beloved and Denver. At the risk of producing a formulaic interpretation of the text, we nevertheless read Sethe as representative of a tragic hermeneutics of identity, Beloved as representative of a hermeneutics of refusal 
and difference, and Denver as representative of a hermeneutics of response and redress.

\subsection{Madness as depicted in Beloved}

We interrogate Sethe's (attempted) murder of her child(ren) in relation to Foucault's thoughts around madness/unreason as formulated in Madness and civilization (Foucault, 1965). Although Foucault does not clearly distinguish between madness and unreason, there is a marked difference in his conception of these two terms. "Unreason' refers to everything that is beyond reason. It is the "giving way of reason"' (Caputo, 1993:234) and "the mode of access to the natural truth of man'" (Foucault quoted in Caputo, 1993:234). According to Foucault, the meaning of unreason, the "natural truth" to which it gives access, has been lost to modernity, since it has been reduced to silence through reason's powerful practices of confinement, exclusion and moralising discursivity that transform unreason into what modernity knows as madness. "Madness", though originating in unreason, is socially constructed according to hegemonic and ideological forces that operate in different historical periods. As changes occur in societies, so do the meaning, understanding and treatment of madness change. Thus the meaning of madness is wrapped up in the historically and culturally specific discourses of different societies. There is no eternal "capitalized Truth" (Caputo, 1993:233) of madness - madness implies different things at different times.

Foucault theorises that it is only through expressions of unreason in art that modernity can engage with that which lies beyond reason, outside the limiting and restricting discourses of medicine and psychology, which appropriate and control unreason in its guise of madness. For Foucault "[t]he work of art springs not from pure madness [which gives rise only to silence (Caputo, 1993:244)] but from the invasion of reason by madness, from the tension or confrontation between reason and unreason" (Caputo, 1993:242). Morrison's text conforms to Foucault's understanding of unreason in art when he says:

[A] work of art opens a void, a moment of silence, a question without answer, provokes a breach without reconciliation where the world is forced to question itself. ... [T] he world is made aware of its guilt. ... [T] he world ... becomes culpable ... it is now arraigned by the work of art, obliged to order itself by its language, compelled by it to a task of recognition, of reparation, 
to the task of restoring reason from that unreason and to that unreason.

(Foucault, 1965:288)

We read Morrison's representation of Sethe's (attempted) murder of her child(ren) as an artistic representation of "the voice[...] of unreason that [...] speak[s] of 'human truth' and 'dark freedom"' (Caputo, 1993:240). Sethe dwells "at that limit point where the world comes undone, where it is unmad" (Caputo, 1993:241) and she represents the confrontation between reason and unreason.

By presenting the "giving way" (Caputo, 1993:233) of Sethe's reason outside of the moralising and confining discursive categories of psychology and psychiatry, Morrison opens a channel of communication that engages the reader with the unfiltered experience and knowledge of unreason, which Caputo, following Foucault, interprets as the "tragic" and "terrible" "truth" (Caputo, 1993:237) of being driven to the extremes of human sensitivity. Caputo (1993: 238) says:

[t]he mad speak de profundis, from the depths of an experience in which both the reassuring structures of ordinary life and the comforting reassurances of scientific or philosophical knowledge have collapsed. They experience the radical groundlessness of the world, the contingency of its constructs, both social and epistemic, they speak of and from a kind of ineradicable terror. They speak to us from the abyss by which we are all inhabited, they are voices from an abyss.

Morrison challenges the normalisation and institutionalisation of "capitalized Truths" through her representation of "the confrontation of reason and unreason in [a] concrete historical context" (Caputo, 1993:244). Foucault (1965:ix) calls for this in Madness and civilization (1965), when he says "we must renounce the convenience of terminal truths". In Beloved, it is through the character of Sethe and her disturbing act of unreason that Morrison interrogates and subverts Western ideological conceptions of freedom, maternity and humanity.

\section{Sethe as representation of a tragic hermeneutics of identity}

Schapiro (1991:195) explains that "psychic death", that results from slavery, involves "the denial of one's being as human subject". Sethe's (attempted) murder of her child(ren) is a reaction to her experience of "radical groundlessness" and "ineradicable terror" (Caputo, 1993:238). This experience stands in the context of 
Sethe's understanding of her own identity as defined in relation to her world and other individuals around her, most specifically her children. Maxwell (2000:250) notes that

[Sethe's] act of infanticide can only be apprehended through an understanding of the key emotional experiences in [her] slave past, isolated but critical events that for her coalesce in the knowledge of the heart to reveal the unbearable horrors of bestial servitude awaiting her offspring.

She is confronted with the knowledge that she cannot determine or define her identity and that her new understanding of herself, and her children, as "free" is neither guaranteed nor irreversible. Caputo equates a tragic hermeneutics, based on the split between reason and unreason, with a hermeneutics of identity, which constitutes an attempt at defining "who we are" and "who we are not" (Caputo, 1993:233).

\subsection{Sethe's experience of "non-personhood"}

Before her flight, Sethe knew life only as a slave, and her identity or, more accurately, her lack thereof - was violently imposed on her from outside. She knew herself only in the context of oppressive ideologies that held that she was less-than-human, an object, and something to be owned and used by others. Schoolteacher's "research" into the animality of slaves reflects the ideological climate under which a slave was defined:

[Sethe had] gone wild, due to the mishandling of the nephew who'd overbeat her and made her cut and run. Schoolteacher had chastised that nephew, telling him to think - just think what would his own horse do if you beat it beyond the point of education. ... Suppose you beat the hounds past that point thataway. ... . ... [S]ee what happened when you overbeat creatures God had given you the responsibility of ...

(Morrison, 1988:150)

Gates and McKay (1997:130) call this the enforcement of a state of "non-personhood", which was the foundation of the socio-economic system of American chattel slavery, and which translates via racist and ethnocentric ideologies into a belief in the animality/nonhumanity of slaves.

Baby Suggs, Sethe's mother-in-law, is the oldest of the novel's characters and the one who spent the longest time, and suffered the greatest loss, under slavery. As the "voice of ... ancestral wisdom" 
(Bouson, 2000:159) and collective memory in the novel, Morrison uses Baby Suggs to present the consequences of slavery's violent imposition of ownership and control:

Anybody Baby Suggs knew, let alone loved, who hadn't run off or been hanged, got rented out, loaned out, bought up, brought back, stored up, mortgaged, won, stolen or seized.

(Morrison, 1988:23)

Baby Suggs is also Morrison's mouthpiece for the expression of a slave's experience of loss/lack of identity when she says "I don't call myself nothing" (Morrison, 1988:141). Morrison (1988:140) describes her as "having never had the map to discover what she was like".

\subsection{Sethe's experience of freedom}

After hearing Schoolteacher discuss her supposed animal traits with his pupils, Sethe is moved to resistance. In a conversation with her husband, Halle, Sethe realises that her children will lose their identities - and possibly even their lives - to slavery:

[Halle said:] '... [Schoolteacher] say it don't pay to have my labor somewhere else while the boys is small.'

[Sethe thought:] ... I couldn't get out of my head the thing that woke me up: 'While the boys is small'. That's what he said and it snapped me awake. They tagged after me the whole day weeding, milking, getting firewood. For now. For now.

(Morrison, 1988:197)

When she flees from Sweet Home, Sethe seizes the agency needed to secure control of her own and her children's lives. She moves from a position in which others define her identity for her, to a new position in which she defines it herself. As she actively attempts to liberate herself from the oppression, abuse and pain that marked her life as a slave, subjection transforms into subjectivity and subjectivity becomes subversion. This act of self-actualisation Morrison calls Sethe's "claiming" of herself. She says:

Bit by bit, at 124 and in the Clearing, along with the others, she had claimed herself. Freeing yourself was one thing; claiming ownership of that freed self was another. (Morrison, 1988:95)

No longer is ownership vested in the slave system and the slave master. She has ceased to be an object and can think of herself, 
speak and act as a subject. Morrison represents subjectivity as a reclamation project and choice as the inherent characteristic of freedom: "[Sethe discovered] how it felt to wake up at dawn and decide what to do with the day" (Morrison, 1988:95).

Sethe's acquaintance with choice is significant, as this empowers her to choose to kill her children rather than have them enslaved. Her killing of her child(ren) is the act of a free woman, since it is only as a free woman that she has the choice to either "save" them by the only means available to her, or to let them go into slavery with Schoolteacher. This is the reason why she did not kill her children at Sweet Home, since it is only as a free woman that Sethe's choice to kill them carries the profound meaning of freedom. Under slavery, with no experience and true understanding of what freedom meant, murder or suicide was not a choice that she could have considered. However, after spending 28 days in freedom, her frame of reference changes and a new choice arises.

Caputo (1993:254) reads Foucault's thoughts on power in this context of the conflict - or "agonism" - between choice and force, and between freedom and enslavement:

Foucault clearly distinguishes the power that is exerted over material objects, for example, by means of instruments, from the power that individuals exert over other individuals, which is not power over things but power over freedom. ... [T] The power in which Foucault is interested is exerted over 'the other', over another person who acts and reacts. Power is a set of actions upon other actions ... [p]ower relations occur in the space between pure force and free consent ... [t]hus power is exerted only over free subjects, and only insofar as they are free ... [p]ower is exerted only over beings capable of being recalcitrant and intransigent. Power implies freedom since without freedom power is just constraint or force. Power and freedom belong together agonistically, in an ongoing 'agonism', a struggle, in which there are winning and losing strategies.

Under slavery, Sethe was an object, owned by someone who could do with and to her what he pleased. He could even kill her if he chose to do so. Her life was in the hands and at the mercy of her "master". As a slave in Kentucky, Sethe was subject to "pure force", but as a free woman in Ohio, she is exposed to "power [that] is exerted only over free subjects ... over beings capable of being recalcitrant and intransigent" (Caputo, 1993:254). After her flight, she develops a sense of "freedom [that] is resistant and persistent enough [to] cause power to tremble" because of its "irrepressibility", 
its "refusal to contract into an identity", its twisting loose from historical forms of life" and its "lack of nature and essence [and] capacity for novelty and innovation" (Caputo, 1993:255).

\subsection{Maternal infanticide}

During her time with her children at Bluestone Road, Sethe learns the meaning of freedom - and of choice - which Paul D expresses as follows: "... to get to a place where you could love anything you chose - not to need permission for desire - well now, that was freedom" (Morrison, 1988:162).

In this state of newfound freedom, Sethe creates a new identity for herself by redefining herself as "mother":

I did it. I got us all out. ... . Each and every one of my babies and me too. I birthed them and I got em out and it wasn't no accident. ... But it was more than that. It was a kind of selfishness I never knew nothing about before. It felt good. Good and right. I was big ... and deep and wide and when I stretched out my arms all my children could get in between. I was that wide. Look like I loved em more after I got here. Or maybe I couldn't love em proper in Kentucky because they wasn't mine to love. But when I got here, when I jumped down off that wagon - there wasn't nobody in the world I couldn't love if I wanted to ...

(Morrison, 1988:162)

Social and cultural convention holds that it is "natural" for a mother to behave in a certain way and to do certain things and that it is "unnatural" to be otherwise and do different things. This view supports an existing dualism in which qualities such as selflessness, nurturance, self-sacrifice and protectiveness are associated with motherhood. In this dualistic framework, maternal infanticide is in direct opposition to these traditional and culturally accepted qualities of motherhood. Patricia Pearson (1997:73-74) explains that

Our myths about maternal grace - under pressure, pure as nature - are so deeply ingrained that infanticide is the one crime to be all but ignored in discussions of violence. ... When women ... commit neonaticide, they tend not to be considered women, exactly. In other words, they are not mothers in a culturally understood and celebrated way. Mothers are strong, long-suffering, altruistic, and resourceful. Mothers are never callous, they are not indifferent.

In acting in a way that is "unnatural" Sethe transgresses the boundary between that which is socially and morally acceptable and 
that which is not. She moves from a position in which she conforms with what her society prescribes and encourages - a nurturing maternity - to a position in which she expresses her nurturing maternity in a manner that is proscribed and condemned by her society. When Sethe's emotions of love, compassion, empathy and nurturance, which are deemed "natural" for a mother, drive her to protect her children, she is, ironically, judged to be devoid of these very emotions and of humanity. Her friend and lover, Paul D, tells her "[y]ou got two feet Sethe, not four" (Morrison, 1988:165). Morrison (quoted in Rothstein, 1987:17) describes the precarious boundary of mother love as follows:

One of the nice things that women do ... is nurture and love something other than themselves - they do that rather nicely. Instinctively, perhaps, but they are certainly taught to do it, socialized to do it, or genetically predisposed to it - whatever it is, it's something that I think the majority of women feel strongly about. But mother love is also a killer. ... Sometimes people say, well, your children become yourself. But it's not that. It's just that they become what [Sethe] says in the book, [and] that's the best part of me. That's what maternity is. So you do some extraordinary things if that's what you really believe[.] ... You can really control other people's lives. You can tell them when to move and what to do, and part of this is parental obligation and part of it is excessive. And this woman [Sethe] does something during slavery - she was trying to be a parent and a mother and have something to say about her children's lives in a slave system that said to blacks, 'You are not a parent, you are not a mother, you have nothing to do with your children'.

The tragic irony of Sethe's infanticide lies in her duplication of the power dynamics to which she had been subjected all her life. Just as the slave master chooses how to use and dispose of his slaves (what Schoolteacher calls the "creatures God had given you the responsibility of" - Morrison, 1988:150), so Sethe also does with her children. Though her intentions are good - she says: "my plan was to take us all to the other side where my own ma'am is" (Morrison, 1988:203), the consequences are similar. Like the slave master, Sethe also assumes and claims for herself the right to control others (Maxwell, 2000:254). She claims ownership of her children, as Jennifer Uglow (quoted in Pearson, 1997:88) explains: "Sethe could not have killed her child unless she thought she owned her." Morrison eloquently describes this irony as follows: "She did the right thing, but she didn't have the right to do it" (Morrison quoted in Denard, 1991:317-338; Otten, 1993:657). 


\subsection{The disintegration of Sethe's new self-defined identity}

Having been a slave all her life, then believing herself to be free, Sethe is confronted with the reality of a return to slavery and "nonpersonhood" (Gates \& McKay, 1997:130) with the arrival of Schoolteacher at Baby Suggs' house. The moment in which she recognises Schoolteacher marks the disintegration of her newfound and self-defined identity. The approaching group of white men under the leadership of Schoolteacher is represented as "a portent of death" (Bouson, 2000:145) in their appearance as the apocalyptic "four horsemen" (Morrison, 1988:148). Bouson (2000:145) points to the correspondence between Morrison's depiction of malevolent and portentous whites encroaching on the inhabitants of 124 Bluestone Road and bell hooks's description of "representations of whiteness in the black imagination" as "terrorizing". The moment of Schoolteacher's approach marks Sethe's "giving way of reason" (Caputo, 1993: 234), from which her act of unreason flows:

... she was squatting in the garden and when she saw them coming and recognized [S]choolteacher's hat, she heard wings. Little hummingbirds stuck their needle beaks right through her headcloth into her hair and beat their wings. And if she thought anything, it was No. No. Nono. Nonono. Simple. She just flew. Collected every bit of life she had made, all the parts of her that were precious and fine and beautiful, and carried, pushed, dragged them through the veil, out, away, over there where no one could hurt them. (Morrison, 1988:163)

... she flew, snatching up her children like a hawk on the wing; [...] her face beaked, [ ] her hands worked like claws, [...] she collected them every which way: one on her shoulder, one under her arm, one by the hand, the other shouted forward into the woodshed filled with just sunlight and shavings ...

(Morrison, 1988:157)

Sethe's murderous act is an attempt to save her children, not only from slavery, but also from the knowledge and truth of human existence, specifically "black" existence, the thought that they will always be subjected to definitions and identities imposed on them by others. Thus she articulates her maternal responsibility as follows: "It's my job to know what is and to keep them from what I know is terrible. I did that" (Morrison, 1988:165).

Sethe believes that these murders will be an act of salvation: "I took and put my babies where they'd be safe" (Morrison, 1988:164). This belief corresponds with Caputo's tragic hermeneutics of identity and 
the experience of unreason "at the limits of the constitution of the world, where the world threatens to come undone, to deconstitute itself" (Caputo, 1993:240). The world beyond death carries for Sethe the promise of the salvation, unification and liberty that are unattainable for her and her children in life. At the moment when reason gives way to unreason, an act as utterly unreasonable as the killing of her children becomes the most reasonable of acts for Sethe. It is the final and ultimate act of maternal salvation available to her.

Sethe's "experience [of] the radical groundlessness of the world, the contingency of its constructs ... [and] ... a kind of ineradicable terror" (Caputo, 1993:238) lies at the heart of Morrison's novel. Sethe experiences the inherent absurdity of human existence. She realises that she cannot definitively construct her identity. She understands that she is consumed by a "depth of negativity" (Caputo, 1993:237) that makes all things possible - even a return to slavery and the salvation of her children through murder.

\subsection{Sethe as symbol of tragic truth and hopefulness}

Caputo reads Foucault's early works, specifically Madness and civilization (1965), as speaking of a tragic truth that has been repressed and that needs to be recovered in order for "reason to constitute itself as an identity" (Caputo, 1993:239). This truth that needs to be recovered is the knowledge that reason and unreason are inseparable, that one is always implicit in the other, and that identity can only be constituted through the acknowledgement, acceptance and understanding of this complex relationship. This interactive bond between reason and unreason is reflected at the end of the novel. As the community re-integrates Sethe, the symbol of unreason in their midst, she must learn to live with an integrated understanding of herself. As she recovers the tragic truth of her own existence, she must come to understand that she is "[her own] best thing" (Morrison, 1988:273). Read from this perspective, Beloved can be viewed as "[a] work where there is healing and the prospect of a new beginning. For all its sadness, it has a hopeful ending" (Denard, 1991:317-338; Bouson, 2000:160).

\section{Beloved as representation of a hermeneutics of refusal and difference}

The second kind of hermeneutics that Caputo identifies is a hermeneutics of refusal and difference, of which Morrison's character Beloved is representative. We read Beloved in the context 
of Caputo's understanding of a "new repression" that emerges in Foucault's later work. Caputo (1993:251) calls this a repression of the "capacity for being-different":

It is no longer an identity we need to recover (a secret tragic identity) but a difference. It is no longer a positive ideal that needs to be restored but simply a certain capacity to resist the identities that are imposed upon us just in order to set free our capacity to invent such new identities for ourselves as circumstances allow. (Caputo, 1993:256)

From her first appearance, Beloved's difference is apparent. Like a baby, emerging from the water of its mother's womb, Beloved emerges as "[a] fully dressed woman walk[ing] out of the water" (Morrison, 1988:50). Like an infant, she has to "negotiate the weight of her eyelids", while "her neck ... keep[s] bending" and her skin is "new [...], lineless and smooth" (Morrison, 1988:50). Though she is a grown woman, she conducts herself like a child, sleeping frequently, soiling her bedclothes, constantly in need of feeding, displaying a fondness for sweet, sugary food and speaking in an inarticulate child-like manner. Though Sethe and Denver notice her difference, it is Paul D who openly acknowledges Beloved's difference when he tells Sethe: "[s]omething funny "bout that gal"" (Morrison, 1988:56).

Though Caputo (1993:252) focuses on "the negative freedom of the individual to be different", we read Beloved as more, namely as the actualisation of this "capacity for being-different" in the context of African-American history. She personifies the quest "to understand how we have been trapped in our own history" (Foucault quoted in Caputo, 1993:249). We focus on Beloved's need for acknowledgement and recognition through naming, and read this as representative of a quest for self-constitution through a reconstitution of the past.

\subsection{Beloved and African-American history}

The character Beloved is in first instance the embodiment of an African-American socio-cultural crisis of historical alienation and disconnection. Beloved's lack of knowledge of her origins - Sethe calls it her "disremembering" (Morrison, 1988:118) - stands for the way in which contemporary African-Americans have become alienated from their origins in Africa and in slavery. Morrison refers to this sense of dislocation and alienation in a 1989 interview (Denard, 1991:317-338) and identifies it as her motivation for writing Beloved: 
There is no place you or I can go, to think about or not think about, to summon the presences of, or recollect the absences of slaves; nothing that reminds us of the ones who made the journey and of those who did not make it. There is no suitable memorial or plaque or wreath or wall or park or skyscraper lobby. There's no 300-foot tower. There's no small bench by the road. There is not even a tree scored, an initial that I can visit or you can visit in Charleston or Savannah or New York or Providence or, better still, on the banks of the Mississippi. And because such a place doesn't exist (that I know of), the book had to.

Bouson (2000:132) points out that in Beloved Morrison remembers "the horror and humiliation of slavery" and accepts responsibility for the "unburied, or at least unceremoniously buried" slaves of American history. He sees Morrison's "telling [of] the story of the forgotten slaves" (Bouson, 2000:132) as a reclamation of authority and power over African-American cultural memory. It is in this spirit of historically constitutive remembering that African-American literary critic, Barbara Christian (1993), calls Beloved "not just a novel, but a prayer, a healing ritual for our country's holocaust of slavery".

Thus the small scars on Beloved's forehead and throat, the only blemishes on an otherwise perfect body, are indicative of her relationship with the dead slaves of African-American history. These scars are physical signs of Sethe's killing of her baby girl, an act intended to keep her children safe from slavery (Maxwell, 2000:247 $\& 257)$. Through reverse symbolism the scars on Beloved's body, intended to keep her from slavery, become symbolic of the deaths of millions of Africans under slavery. It is in this context that Morrison's epigraph to Beloved gains its significance: "Sixty Million and more". Beloved is symbolic of social relationships that have ceased to exist and of a fractured community in need of healing and reconstruction. She "historicizes the personal [and] in so doing, [...] emphasizes the role of personal and communal agency in building a 'home' for African American community" (Kella, 2000:14).

Caputo (1993:250) understands a hermeneutics of refusal and difference as a project of 'interpreting the 'struggles' we witness nowadays". He says:

... [T] hese struggles are not for or against the 'individual', but rather they are struggles against the 'government of individualization' ... the very business of coming up with normative ideas of what the individual should be ... 
For Caputo, this refusal is an insistence upon the "right to be different" (Caputo, 1993:252) and the "capacity to resist the identities that are imposed upon us" (Caputo, 1993:256). A hermeneutics of refusal and difference entails the investigation and interpretation of human behaviour and social institutions by "approach[ing] the processes of subjection by way of consideration of the 'resistance' that is offered to them, of the 'antagonisms' that they engender" (Caputo, 1993:250). According to Caputo,

[s]uch struggles 'assert the right to be different and they underline everything which makes individuals truly individual' and they fight against everything that 'ties [the individual] to his own identity in a constraining way', which reduces the individual to the identity of 'madman', 'mentally retarded', 'alcoholic', 'handicapped', etc.

In representing Beloved, in her relationship to the "Sixty Million and more" lost and forgotten slaves of the novel's epigraph, as a symbol of African-American history, Morrison places her in a violent engagement with the pacifying discourses of racism and Western historicity. Through her increasing refusal of docility and conformity, Beloved inhabits a space that corresponds with Caputo's understanding of a Foucaultian hermeneutics of refusal and difference. The inescapability of history is presented through Beloved's increasing invasiveness, as she clings to Sethe "like a familiar" (Morrison, 1988:57) and it becomes impossible for Sethe to remain disengaged from her slave past. Beloved's strangling of Sethe in the Clearing marks the moment when, for the first time, Sethe relates Beloved to her dead baby: "[she had] the suspicion that the girl's touch was also exactly like the baby's ghost" (Morrison, 1988:99). Morrison in this respect leads the reader into an engagement with American history, collective memories and the "ghosts" of the past:

When Denver later accuses Beloved of making Sethe choke, Beloved claims that Sethe was choked by the 'circle of iron' [101] - that is, the iron collar used to restrain the slaves. If Sethe's frightening experience is the repetition of a collective trauma, it also is the repetition of a family trauma. For Sethe's near-strangulation, as she helplessly claws at invisible hands and thrashes her feet in the air, is a rememory of the murder of the baby who died by having its throat slit. In this rememory, however, the victimized baby/reincarnated ghost turns the tables and exacts revenge by victimizing Sethe.

(Bouson, 2000:151) 
Morrison uses Baby Suggs to widen the focus from Sethe's personal ghost to the greater context of African-American history:

Not a house in the country ain't packed to its rafters with some dead Negro's grief. We lucky this ghost is a baby. My husband's spirit was to come back in here? Or yours?

(Morrison, 1988:5)

Ella's comment to Stamp Paid, "You know as well as I do that people who die bad don't stay in the ground" (Morrison, 1988:188), is an acknowledgement of the impropriety of America's slave deaths. Beloved's resurrection of the past is an African-American rebellion against America's dismissal of the lives that were lost under slavery and Beloved's return to life is a refusal to be dismissed and forgotten, an insistence on America's addressing of unfinished business, which Heinze and Lewis (1994:171-187) describe as "a purging of the guilt of the American psyche".

\subsection{Beloved's fear of disintegration and need for identity formation}

Having been a spirit without body, Beloved reconstitutes herself in embodied form in an attempt to undo the separation of spirit and body that resulted from her murder. When her tooth falls out, she fears that it signals the beginning of her disintegration:

Beloved looked at the tooth and thought, this is it. Next would be her arm, her hand, a toe. Pieces of her would drop maybe one at a time, maybe all at once. ... It is difficult keeping her head on her neck, her legs attached to her hips when she is by herself. ... She had two dreams: exploding and being swallowed. When her tooth came out - an odd fragment, last in the row - she thought it was starting. (Morrison, 1988:133)

Beloved's fear of disintegration speaks of the dangers of historical forgetfulness and her fear of being "swallowed" is a reminder of the experiences of her ancestors in the dark holds of slave ships.

Beloved's need is for the constitution of her identity as well as a social context within and against which she can construct and define herself. She fears disintegration most when she is alone and momentarily disconnected from Sethe and Denver, who provide her with an immediate context of family relations: "[she feared that] on one of these mornings before Denver woke and after Sethe left she would fly apart" (Morrison, 1988:133). 
Sethe senses Beloved's desire for (re)constitution soon after her arrival:

... [Sethe] was sliding into sleep when she felt Beloved touch her. A touch no heavier than a feather but loaded, nevertheless, with desire. ... The longing she saw [in Beloved's eyes] was bottomless. Some plea barely in control. (Morrison, 1988:58)

What Beloved requires is to be acknowledged, remembered, known, and named, and it is Sethe, the woman who is both her creator and destroyer, who can provide this.

When Paul D interrogates Beloved about her identity and origins, she cannot tell him who she is, because without Sethe she is nobody. She tells Paul D and Denver

'I don't have nobody.'

'What was you looking for when you came here?' he asked her.

'This place. I was looking this place I could be in.'

(Morrison, 1988:65)

'I don't want that place. This the place I am.'

(Morrison, 1988:123)

The place that Beloved does not want is death, where she will be alone and forgotten like all the other victims of the Middle Passage and of slavery. Beloved wants to belong, and she wants to be acknowledged and celebrated as a member of her family and community. Her insistence on finding a "place where [she] could be in" (Morrison, 1988:65) is simultaneously her refusal to accept the way America has dealt with the memory of its African slaves. In order to "recollect the absences of slaves" (Morrison quoted in Denard, 1991:317-338), Beloved insists on hearing Sethe's stories of the past. Initially Sethe is amazed at the "profound satisfaction Beloved got from storytelling" (Morrison, 1988:58), but later she too finds that remembering the past becomes "an unexpected pleasure" (Morrison, 1988:58). In telling Beloved about her past, "[Sethe] was remembering something that she had forgotten she knew" (Morrison, 1988:61). Beloved's need for (re)constitution also serves Sethe's own need for the same.

\subsection{The significance of naming in the constitution of identity}

The constitution of identity through the acknowledgement and celebration of the past translates into Beloved's insistence on being named. When seducing Paul D, she insists that he name her: "You 
have to touch me. On the inside part. And you have to call me my name. ... Call me my name. ... Please call it" (Morrison, 1988:117).

Beloved's memories of the "dark" place of death reflect the historical significance of the absence of her name. In a conversation with Denver she recollects

'Why you call yourself Beloved?'

Beloved closed her eyes. 'In the dark my name is Beloved'.

Denver scooted a little closer. 'What's it like over there, where you were before? Can you tell me?'

'Dark,' said Beloved. 'I'm small in that place. I'm like this here.'

She raised her head off the bed, lay down on her side and curled up.

Denver covered her lips with her fingers. 'Were you cold?'

Beloved curled tighter and shook her head. 'Hot. Nothing to breathe down there and no room to move in.'

'You see anybody?'

'Heaps. A lot of people is down there. Some is dead.'

'You see Jesus? Baby Suggs?'

'I don't know. I don't know the names.' She sat up.

(Morrison, 1988:75)

Beloved's name serves as a symbolic connection to the ancestors. The reader never learns what Beloved's real name is, and this omission of Beloved's real name functions as a strong link to the nameless "Sixty Million and more". The name by which the reader knows her speaks not only of the loving remembrances due to the dead ancestors, but also of the manner in which Western ideologies and systems of power have silenced African conventions, traditions, beliefs and rituals. Beloved's death and grave are marked by Christian liturgy and ritual ("Dearly Beloved ..." - Morrison, 1988:5) and not by the memorials and rituals of African traditions.

\section{Denver as representative of a hermeneutics of response and redress}

The third kind of hermeneutics that Caputo identifies in Foucault's work is a hermeneutics of response and redress, along with which he envisions a therapeutics of healing gestures. He states that "there is nothing in what Foucault says that opposes 'a strategy of cure'; it is simply not his subject" (Caputo, 1988:259). Caputo 
(1993:259) reminds one that "madness is also a being-disturbed ... a way of suffering that causes pain" and that "the mad" need healing: "Their cry of pain is also a cry for help" (Caputo, 1993:259). We read Denver in this context as representative of healing, and we focus our reading on her association with salvation and forgiveness. Denver represents a successful constitution of identity, one which acknowledges and celebrates the past without being dependent on it for self-actualisation.

\subsection{Correspondences between Sethe and Denver}

Denver can be read as a continuation, or fulfilment, of the potential that Sethe discovers in herself during her days of freedom before the murder. Like Sethe, Denver also flees from her confinement. While Sethe's confinement is slavery, Denver is confined by Sethe's memories and past actions. Like Sethe, Denver also seizes the agency needed to save herself. Sethe flees from Sweet Home, and Denver leaves 124 Bluestone Road to educate herself, first as a young child to attend Lady Jones' school and later to work in Cincinnati and possibly go to college. Both Sethe and Denver construct their identities around independence and freedom. Denver's sense of pride and accomplishment after her first visits to Lady Jones' school is similar to Sethe's feelings after being reunited with her children and Baby Suggs:

[Denver] was seven and those two hours in the afternoon were precious to her. Especially so because she had done it on her own and was pleased and surprised by the pleasure and surprise it created in her mother and her brothers.

(Morrison, 1988:102)

I did it. I got us all out. Without Halle. Up till then it was the only thing I ever did on my own. Decided. And it came off right, like it was supposed to. Each and every one of my babies and me too. I birthed them and I got em out and it wasn't no accident.

(Morrison, 1988:162)

As Sethe did after her arrival at Baby Suggs' house, Denver also creates a new identity for herself when she leaves home to work in Cincinnati. Yet, unlike Sethe, Denver, who does not have to navigate the memories and rememories of a life spent under slavery, has a healthy relationship with the past, in the sense that she neither "disremembers" (Morrision, 1988:118) nor wallows in the pain and losses of the past. Denver transcends her personal history and her roots in slavery, to emerge in control of her present life, cognisant of her past, and enthusiastic about her future. 


\subsection{Denver and salvation}

From early in the novel, Denver is associated with the idea of salvation. Initially the reader sees her waiting to be saved - Paul D tells Sethe that Denver has "got a waiting way about her [...] ... [s]omething she's expecting" (Morrison, 1988:41). She dreams of salvation in the safe house she creates in the boxwood bushes that grow behind Sethe's house:

First a playroom (where the silence was softer), then a refuge (from her brothers' fright), soon the place became the point. In that bower, closed off from the hurt of the hurt world, Denver's imagination produced its own hunger and its own food, which she badly needed because loneliness wore her out. Wore her out. Veiled and protected by the live green walls, she felt ripe and clear, and salvation was as easy as a wish.

(Morrison, 1988:29)

In the course of the novel, Denver grows from the one in need of salvation, to her own and her mother's saviour:

... it was [Denver] who had to step off the edge of the world and die because if she didn't they all would. (Morrison, 1988:239)

... Denver decided to do the necessary. Decided to stop relying on kindness ...

Somebody had to be saved, but unless Denver got to work, there would be no one to save, no one to come home to, and no Denver either. It was a new thought, having a self to look out for and preserve.

(Morrison, 1988:252)

Initially Denver associates Beloved with the salvation for which she has been waiting. She needs Beloved's attention to be constituted as an individual. When Beloved leaves her alone in the cold house Denver cries "because she has no self" (Morrison, 1988:123). Beloved lends Denver a context within which she can define herself, since after Beloved's arrival, Denver conceptualises herself as a caretaker, babysitter, friend, protector, educator and, finally, sister, whereas before Beloved, she was lonely, disconnected and alienated. Through Beloved, Denver feels herself constituted and vibrantly alive:

... Beloved rested cheek on knuckles and looked at Denver with attention. It was lovely. Not to be stared at, not seen, but being pulled into view by the interested, uncritical eyes of the other. Having her hair examined as a part of her self, not as material or a style. Having her lips, nose, chin caressed as they might be if she were a moss rose a gardener paused to admire. Denver's 
skin dissolved under that gaze and became soft and bright ... . She floated near but outside her own body, feeling vague and intense at the same time. Needing nothing. Being what there was.

And to be looked at by [Beloved], however briefly, kept [Denver] grateful for the rest of the time when she merely was the looker.

(Morrison, 1988:118-119)

At the end of the novel, Denver succeeds in breaking away from her destructive need to have her identity constituted from outside. According to Schapiro (1991:206), "ultimately Denver is able to escape the narcissistic vacuum" and "[e]xcluded from the BelovedSethe dyad, [she] is forced into the role of the outsider, and assuming that role is her salvation". In this salvationist moment of escape, which Morrison (1988:239) calls "step[ping] off the edge of the world" ..., "Denver for the first time begins to experience the contours of her own separate self" (Schapiro, 1991:206). Schapiro continues:

Self-recognition is inextricably tied up with self-love, and this is precisely the message of the sermons that Baby Suggs preaches to her people in the Clearing. In a white society that does not recognize or love you, she tells them, you must fight to recognize and love yourself.

\subsection{Denver's attainment of self-love and healing}

Otten (1989:92) agrees with a reading that interprets Denver as emblematic of the (re)discovery both of self-love and selfdetermination, as well as communal reconciliation and healing. $\mathrm{He}$ says:

Once Denver begins to comprehend the enormity of Sethe's love and experience 'shame' for her mother's suffering, she herself becomes morally alive. She can assume responsibility and reunite others in the struggle to restore wholeness to a fallen community.

(Otten, 1989:92)

Denver's potential to reconstitute herself in connection to, but not in reliance upon the past is apparent in her lack of interest in stories that do not revolve around her. The story of her own birth is what she fixates on, and this later becomes indicative of her rebirth into the new self-sufficient and self-confident Denver, who like her namesake, Amy Denver, travels to the city to reconstruct her identity. Of the novel's trinity of major characters, Denver is the only 
one who manages effectively to negotiate the trauma of the past, of which she partakes, unlike Sethe and Beloved, second-hand. Sethe and Beloved, on the other hand, are fixated on stories of the painful past that lead to their inability to function independently outside of their rememories. Sethe is caught up in a destructive cyclical dependence on the past, as she believes that the pain of the past returns and is inescapable. She tells Denver:

Some things go. Pass on. Some things just stay. I used to think it was my rememory. You know. Some things you forget. Other things you never do. ... The picture is still there and what's more, if you go there - you who never was there - if you go there and stand in the place where it was, it will happen again; it will be there for you, waiting for you. So, Denver, you can't never go there. Never. Because even though it's all over - over and done with - it's going to always be there waiting for you ...

(Morrison, 1988:36)

Bouson (2000:135) reads this passage as significant in the understanding of the trauma of Beloved:

There remains at the center of the trauma survivor, as Dori Lamb has remarked, 'a danger, a nightmare, a fragility, a woundedness ...'. .... Sethe's account of her 'rememory' - that is, her uncontrolled remembering and reliving of emotionally painful experiences - recalls descriptions of a visual form of memory that trauma investigators refer to as traumatic memory.

Both Sethe and Beloved are unable to extract themselves from their memories of, and involvement with the past. Beloved's traumatisation (her own murder and the murder of the millions of ancestors) is depicted in her fragmented and dissociated "song" that forms the "moment of historical recollection and narrative rememory of the collective experience of the Middle Passage" (Bouson, 2000:153). Beloved's rememory of this experience corresponds with her earlier rememory, which she tries to explain to Denver of the "dark place" beyond death (Morrison, 1988:74), reminiscent of the holds of slave ships, from which she returns to Sethe. Both experiences are remembered for the same traumatic aspects of darkness, heat, cramped bodies, thirst and an inability to breathe.

\subsection{Denver and forgiveness}

Throughout the novel, Denver is also associated with forgiveness. She succinctly summarises the destructive relationship of Beloved and Sethe as revolving around a need for forgiveness: "It was as 
though Sethe didn't really want forgiveness given; she wanted it refused. And Beloved helped her out" (Morrison, 1988:253).

Moglen (1997:12) notes that "Denver realizes that the desire of each [Beloved and Sethe] to return to a place in which she can merge with and possess the other" initiates a life-and-death struggle that neither can survive.

Early in the novel Denver, like Sethe later, is represented as seeking Beloved's forgiveness and acceptance through various pacifying actions and gestures: "Blinking fresh tears Denver approached Beloved - eager for a word, a sign of forgiveness" (Morrison, 1988:105).

Denver's need for forgiveness from Beloved, like Sethe's, is in response to her own feelings of guilt. Sethe feels guilty because she killed her child. Denver feels guilty that she escaped unscathed from their mother's attack, while her sister died. As we have already shown, Beloved functions as a connection to the millions of African ancestors who died as slaves. Denver, conversely, stands for those in post-bellum and contemporary America, who survived slavery to live as free women and men. Reading Beloved as a "purging of the guilt of the American psyche" (Heinze \& Lewis, 1994:171-187) implies a recognition, not only of the collective historical guilt of American whites for what was done to enslaved Africans and their ancestors, but also of the guilt of present-day African Americans for their disconnection and "disremembering" (Morrison, 1988:118) of their painful history. Denver's ambivalent feelings about her birth as a free person - on the banks of the Ohio exemplify her emotional confusion:

This was the part of the story [her birth] that she loved. ... she loved it because it was all about herself; but she hated it too because it made her feel like a bill was owing somewhere and she, Denver, had to pay it. But who she owed or what to pay it eluded her.

(Morrison, 1988:77)

\subsection{Passing on the story}

In the novel's postscript Morrison (1988:275) says that the story of Beloved "was not a story to pass on". This phrase could be understood to mean that Beloved's story should not be forgotten (passed on), while at the same time meaning that it should not be retold (passed on). Morrison's narrative act of writing this novel belies the second meaning (Kella, 2000:228). The political implication of her writing this novel is that Beloved's story, and 
through her the story of American slavery, is something to pass on (to retell), as such retelling "attempts to transform the shame and pain of slavery into artistic pride" (Bouson, 2000:162). Denver acts as the novel's catalyst, for she embodies this change from shame and fear to pride and self-respect. Beloved's story becomes worthy of being passed on because of Denver's redemptive role in the novel. Because of Denver's embodiment of hope for the future, the story of Beloved and the now reconstituted and remembered slave ancestors must be passed on at all cost, to ensure the preservation of the valuable, and increasingly valued wisdom that is to be derived from African-American history. Schapiro (1991:209) notes that

[t]he poignancy of Beloved's story/self is that it is not a story/self. She has been denied the narrative of her being, the subjectivity and continuity of inner experience that should be everyone's birthright.

In this novel Denver, who is the embodiment and promise of healing, acts as a counterbalance to Beloved. She claims the birthright of "subjectivity and continuity of inner experience"" (Schapiro, 1991: 209) for all African Americans. Through Denver the novel becomes a "healing ritual" (Christian, 1993) and a "fixing ceremony" (Morrison, 1988:86). It is through her that a hopeful future is envisioned at the end of the novel, since it is Denver who sets in motion the chain of events that leads to the exorcism of Beloved and the communal reincorporation of Sethe. In reaching out to her community, Denver is responsible for healing the schism that separated the community from Sethe. The community transcends its fear and suspicion of Sethe, who symbolises the "deeper rupture" (Caputo, 1993:259) in each of their own psyches.

\section{The value of Caputo's theory for a reading of Beloved}

In a time when images of terror, torture and dehumanisation are all too accessible and invasive, Morrison's Beloved reminds one of the sad fact that there is a historical context and continuum of violence and suffering - and that none of the horrific incidents and images which we encounter daily in our newspapers and on our television screens is unique or novel. Despite its historic specificity, or maybe because of it, Morrison's Beloved speaks of a "common fate" of existential angst and uncertainty. It "affirms [...] community and solidarity" and tells us that "[we] are not alone, that our common madness is a matter of degree, that we are all siblings in the same night of truth" (Caputo, 1993:260). 
Yet, in the final instance Beloved is a novel about hopefulness. Through the character of Denver, Beloved is an articulation of, and insistence upon compassion, forgiveness and healing. Denver is the personification of what Caputo (1993:255) calls a "transcendence" and of "the capacity to move beyond a particular historical constitution". In reading Beloved in the context of Caputo's theory of progressive hermeneutics, the novel's dynamic move towards hopefulness and healing becomes more pronounced. Caputo's work is especially valuable in the reading of Beloved as it presents a framework for the reading of human experiences of suffering and pain which incorporates into "the inescapability of interpretation" (Caputo, 2003) a vision of the possible transcendence of pain and suffering.

\section{List of references}

BJORK, P.B. 1992. The novels of Toni Morrison: The search for self and place within the community. New York: Peter Lang.

BOUSON, J.B. 2000. Quiet as it's kept: Shame, trauma, and race in the novels of Toni Morrison. Albany: State University of New York Press.

CAPUTO, J. 1993. On not knowing who we are: madness, hermeneutics, and the night of truth in Foucault. (In Caputo, J. \& Yount, M., eds. Foucault and the critique of institutions. Pennsylvania: The Pennsylvania State University Press. p. 233-262.)

CAPUTO, J. 2003. Deconstruction, hermeneutics, phenomenology, continental philosophy of religion. Villanova University: John D. Caputo. http://www52. homepage.villanova.edu/john.caputo/ [28 Jan. 2003].

CHRISTIAN, B. 1993. Toni Morrison: Our saving grace. http://garnet.berkeley. edu:3333/.mags/.cross/.38/.black/.bmorris.html [1 May 1997].

DENARD, C.C. 1991. Modern American women writers. http://www/LitRC? $\mathrm{c}=7 \& \mathrm{ai}=163823 \& \mathrm{ste}=6 \&$ doc Num $=\mathrm{H} 1479001308 \& \mathrm{bConts}=16303 \& \mathrm{tab}=1 \& \mathrm{v}$ rs [29 May 2002].

FOUCAULT, M. 1965. Madness and civilization: A history of insanity in the age of reason. New York: Pantheon Books, a division of Random House.

GATES, H.L. Jr. \& McKAY, N.Y., eds. 1997. The Norton anthology of African American literature. New York: Norton.

HEINZE, D. \& LEWIS, C.E. 1994. Toni Morrison. (In Kibler, J.E. Jr., ed. Dictionary of literary biography. Volume 143: American novelists since World War II. Third Series. Detroit: Gale Research. p. 171-187.)

JOYNER, N.C. 1980. Toni Morrison. (In Kibler, J.E. Jr., ed. Dictionary of literary biography. Volume 6: American novelists since World War II. Second Series. Detroit: Gale Research. p. 243-247.)

KELLA, E. 2000. Beloved communities: Solidarity and difference in fiction by Michael Ondaatje, Toni Morrison, and Joy Kogwana. Uppsala: Acta Universitatis Upsaliensis. 
MARTIN, J. 1996. On healing self/nature. (In Lykke, N. \& Braidotti, R., eds. Between monsters, goddesses and cyborgs - Feminist confrontations with science, medicine and cyberspace. London/New Jersey: Zed Books. p. 103-119.)

MAXWELL, M. 2000. Male rage and female fury: Gender and violence in contemporary American fiction. Lanham: University Press of America.

MOGLEN, H. 1997. Redeeming history: Toni Morrison's Beloved. (In Abel, E., Christian, B. \& Moglen, H., eds. Female subjects in black and white: Race, psychoanalysis, feminism. Berkeley/Los Angeles: University of California Press. p. 201-220.)

MORRISON, T. 1988. Beloved. London: Picador.

OTTEN, T. 1989. The crime of innocence in the fiction of Toni Morrison. Columbia: University of Missouri Press.

OTTEN, T. 1993. Horrific love in Toni Morrison's fiction. Modern Fiction Studies, 39(3 \& 4):651-667, Fall/Winter.

PEARSON, P. 1997. When she was bad: How women get away with murder. London: Virago.

ROTHSTEIN, M. 1987. Toni Morrison, in her novel, defends women. The New York Times. Late City Final Edition Section C, 17, Aug. 26. http://search.nytimes.com/books/search/b...news+14015+15+wAAA+\%27 Toni\%26Morrison\%27 [22 August 1997].

SCHAPIRO, B. 1991. The bonds of love and the boundaries of self in Toni Morrison's Beloved. Contemporary Literature, 32(2):194-210.

\section{Key concepts:}

Beloved - by Toni Morrison (1988)

Caputo, John: theory of progressive hermeneutics

Foucaultian hermeneutics

Morrison, Toni

therapeutics of healing/wholing

\section{Kernbegrippe:}

Beloved - Toni Morrison (1988)

Caputo, John: teorie van voortgaande hermeneutiek

Foucault se hermeneutiek

Morrison, Toni

terapie van heling/heelwording 